\title{
Exploring the Motive of Muslim Consumers' Intention Toward Goat's Milk Purchasing in Malaysia: A Focus Group Interview
}

\author{
Aimi Fadzirul Kamarubahrin ${ }^{1 *}$, Asmaddy Haris², Syadiyah Abdul Shukor ${ }^{3}$, \\ and Jamal Abdul Nassir Shaari ${ }^{4}$ \\ ${ }^{1,2,3,4}$ Faculty of Economics and Muamalat, Universiti Sains Islam Malaysia
}

Submitted: May 2, 2019, Accepted: July 30, 2019, Published: August 4, 2019

\begin{abstract}
This study aims to conceptualize the motive of Muslim consumers' intention toward goat's milk purchasing in Malaysia. Two focus group discussion sessions involving 10 existing Muslim consumers' who are purchased goat's milk were conducted. Preliminary findings from this qualitative study showed that health and price played a significant role in Muslim consumers' intention toward purchasing goat's milk. Other three motives of Muslim consumers' intention toward purchasing goat's milk is taste, religiosity and nutritious. Recommendation for future studies is provided at the end of the paper.
\end{abstract}

Keywords: goat's milk; motives; intention; focus group discussion

\begin{abstract}
Abstrak
Kajian ini bertujuan untuk mengenal pasti motif niat pengguna Islam terhadap pembelian susu kambing di Malaysia. Kajian lepas yang berkaitan telah dibincangkan dan dua sesi perbincangan kumpulan berfokus melibatkan 10 orang pengguna Islam yang membeli susu kambing telah dijalankan. Penemuan awal dari kajian kualitatif ini menunjukkan bahawa faktor kesihatan dan harga memainkan peranan penting dalam niat pengguna Islam untuk membeli susu kambing. Tiga lagi motif niat pengguna Islam terhadap pembelian susu kambing adalah rasa, agama dan khasiat. Cadangan untuk kajian masa depan disediakan pada bahagian akhir artikel.
\end{abstract}

Kata Kunci: susu kambing; motif; niat; perbincangan kumpulan berfokus

* Corresponding author 


\section{INTRODUCTION}

Goat's milk is one of the recent issues in consumers' behavior (Utami, 2014). It is starting to be well known among Malaysian especially by Muslim due to following Prophet Muhammad $(P B U H)$ sunnah (a path, a way, a manner of life; all the traditions and practices of the Prophet that have become models to be followed) (Umar, Rani, Rahman, Aripin, Adnan, Aris \& Salleh, 2017) and it is the milk of choice in most of the world (Harden \& Hepburn, 2011). Despite its high nutrition and beneficial health, goat's milk was also suggested in Al-Quran and Hadith. Goat's milk listed as sunnah food which was consumed by the Prophet Muhammad $(P B U H)$ and it contains nutritional value and beneficial to health (Turconi, Rossi, Roggi \& Maccarini, 2013). In addition, goat's milk is a significant food and nutrient source for people in many countries, up to $55 \%$ total of milk is produced in one country (Haenlein, 2004). Moreover, goat's milk and its products play significant roles in human nutrition (Harden \& Hepburn, 2011). However, according to Umar et al (2017), the odor of goat's milk is one of the reasons prevent Malaysian to purchase and consume goat's milk. Therefore, it is crucial to uncover the Muslim consumers' behavior in Malaysia. A Muslim generally complies with shariah in their daily routine. They normally do basic religious commitment such as begin a day with positive thinking and good intention (niyat), prayer, greet other people nicely (with salam) and keep themselves clean.

The increasing number of the Muslim population in Malaysia and the growing awareness among the recent Muslim generations are seen as the essential reason that triggers behavior modification among Muslim consumers' (Yusoff \& Shukor, 2018). Therefore, it is essential for this study to discover the motive of Muslim consumers' intention of purchasing goat's milk in Malaysia. Motives are one of the factors that need to be explored in order to understand the consumers' behavior perspective in purchasing goat's milk. However, motives cannot be seen or touched. Motives are intangible constructs. Most behavior is multi-motivated.

What motivates Muslim consumers' intention of purchasing goat's milk? There is a conscious and unconscious motivation as discussed by previous studies (Umar, et al., 2017; Rani, Umar, Ramli, Rahman, Abdullah \& Salleh, 2016; Siew, Rahman, Rahman, Haris, Chang, \& Rani, 2016; Chang, Rahman, Rahman, Aris, Siew, \& Rani, 2016). However, they are more often unconscious rather than conscious. It is not necessary at this point to overhaul the tremendous mass of evidence which indicates the crucial importance of unconscious motivation. Previous studies postulated health reason, knowledge, past experience, price and taste as the main reason to purchase goat's milk (Kamarubahrin, 2019; Kamarubahrin, Haris, Shukor \& Shaari, 2018; Haris \& Kamarubahrin, 2016; Kurajdova \& Petrovicova, 2015; Gagic, Jovičić, Tešanović \& Kalenjuk, 2014; Jerop, Kosgey, Owuor \& Chelanga, 2013; Mukhtar \& Butt, 2012; Park \& Haenlein, 2007; Essoo \& Dibb, 2004; Becker, Benner \& Glitsch, 2000). The growing consumers' awareness and steadily growing demand for goat's milk (Siew et al., 2016), have provoked the issue on goat's milk production in Malaysia (Department of Veterinary Perak, 2015).

The growing number of the Muslim population in Malaysia (Kamarubahrin, 2019) has contributed to the increasing demand for goat's milk, hence the revolution 
of information adds to the awareness towards goat's milk consumption. This study will help us to deepen the understanding of Malaysian Muslim behavior as consumers' about their motive and intention towards purchasing goat's milk. Thus, the aim of this study is to conceptualize the motive of Muslim consumers' intention of purchasing goat's milk in Malaysia. The idea is to gather the basic information on what trigger Muslim consumers on the intention to purchase goat's milk. The data obtained for the first objective are useful in the development of a new variable. The study will provide crucial information on Muslim consumers' behavior towards purchasing goat's milk, particularly among Muslim in Malaysia.

\section{Goat's Milk}

The importance of goat as providers of essential food in meat and dairy products has been discussed and documented in many recent journal publications (Haris, Kefeli, Ahmad, Daud, Muhamed, Shukor, \& Kamarubahrin, 2017; Siew et al., 2016; Chang et al., 2016; Rani et al., 2016; Umar et al., 2017; Utami, 2014; Santoso, Setiadi, Kisworo $\&$ Nuswantara, 2012; Haenlein, 2004). Goat's products have historically been used for a multitude of purposes; forming an integral component of the livestock industry, plays a vital role in the socio-economic structure of the rural community (Guney \& Ocak, 2013). Most importantly is the ability of goat to play a role in generating employment and income, capital accumulation, and improving household food security and nutrition (Siew et al., 2016). Many anecdotal experiences about the nutritional and medical benefits of goat's milk have been reported (Haenlein, 2004). Goat's milk and its products play significant roles in human nutrition. Goat's milk has the highest mineral composition of calcium $(\mathrm{Ca})$, phosphorus $(\mathrm{P})$ and potassium $(\mathrm{K})$ compared to cow's and human's milk (Bihaqi \& Jalal, 2010). Moreover, goat's milk also contains a higher level of Vitamin A than cow's milk (Yangilar, 2013). Despite many studies focusing on health benefit and nutritious contents of goat's milk, factors toward purchasing are vital. In the case of goat's milk, consumers' behavior will be influenced by the motive behind the action of purchasing goat's milk

\section{Motives of Muslim Consumers' Intention towards Purchasing Goat's Milk}

Motivation offers a potentially powerful source for understanding the driving forces of consumers' actions (Solomon, Bamossy, Askegaard \& Hogg, 2006). A purchasing motive is a reason why the customers purchase the goods. The motive is the driving force behind the purchase of the goods. Motivation explains the behavior of the consumers' why they are going to purchase goods or use services. Purchasing motive is concerned with the reasons explaining the consumers to make the decision for the action. The consumers' motives may be affected by several reasons such as pride, fashion, fear, safety, love and affection, comfort and convenience, and economy. The term of purchasing motive has been defined as a drive or an urge for which an individual seeks for satisfaction. It becomes a purchasing motive when the individual seeks satisfaction through the purchase of something (Chaubey \& Zafar, 2010). Meanwhile, the motive is an inner urge that moves or prompt a person to some action. According to Fotopoulos and Krystallis (2002), purchasing motives are those influence or consideration which provide the impulse to purchase, include action and determined choice in the purchase 
of goods and services. Thus, this study exploring the motives of Muslim consumers' intention of purchasing goat's milk in Malaysia.

The main motive behind the consumers' attitude towards goat's milk was health. Traditional consumers of goat's milk believed that goat's milk had therapeutic properties and could cure or prevent some diseases (Kumar \& Babu, 2014). Moreover, a longitudinal four-year survey by Harden and Hepburn (2011) in the United Kingdom revealed 66.8\% of those goat's milk consumers did so for medical reasons. In addition, a study by Santoso et al. (2012) in the region of Bogor, Indonesia was made similar conclusions on a survey among the consumers of goat's milk. Besides, the consumers were willing to pay higher prices for goat's milk. This implies that many consumers of goat's milk did not mind about the price of the milk, possibly because of the additional health benefits of goat's milk (Jerop et al, 2013). Moreover, the taste of goat's milk is slightly sweeter than cow's milk. Thus, it becomes the motive of the consumers' in Kenya to purchase goat's milk (Jerop et al., 2013). With respect to food prescriptions in Islam, Muslims have to follow a set of dietary laws intended to advance their well-being, in addition to the five pillars of Islam. However, not only religious motives determine halal consumption, but also health, respect for animal welfare and social issues, such as religious identity and degree of acculturation (Bergeaud-Blackler \& Bonne, 2006; Bonne \& Verbeke, 2006; Bonne, Vermeir, Bergeaud-Blackler \& Verbeke, 2007).

Muslim consumers' is unique because they are binding to Islamic law known as Shariah. Because of this, Muslim consumers' behavior, in general, will totally differ from non-Muslim consumers' behavior regarding purchasing behavior. The Niyat (intention) plays an important role in determining the purchase behavior of a Muslim. Umar bin AlKhattab (May Allah be pleased with him), reported: Prophet Muhammad (PBUH) said, "The deeds are considered by the intention, and a person will get the reward according to his intention". There are several points that differentiate between Muslim consumers' and non-Muslim consumers. A Muslim, in general, seeks for rewards and gains the benefits of doing good deeds. The process begins with the intention and does a good action. The action must comply with Islamic law. Muslim consumers must observe the principle of halal and haram and the concept of priority of needs. In the conceptual priority of needs, goat's milk is classified as healthy products (Harden \& Hepburn, 2011). The consumption of goat's milk must be moderate, point out that when human fulfill their basic needs, they will seek to satisfy higher sets of needs. This becomes the Maslow hierarchy of needs.

\section{RESEARCH METHODOLOGY}

This study employed a qualitative research method as it aims to explore the motives of Muslim consumers' intention toward purchasing goat's milk in Malaysia. For the purpose of achieving the study aims, focus group discussions were conducted for the exploration and discovery of the research topic. A focus group is particularly useful for exploration and discovery (Krueger, 2002). By forming a group of individuals together and inducing a topic of discussion toward the collective attitudes and beliefs of the participants, the dynamic transmission of ideas will yield untapped responses and meaningful information (Gerritsen, 2011). Although conducting a focus group can be very time consuming, it produces very rich and in-depth data expressed in respondents' 
A.M. Kamarubahrin, et al, Exploring the Motive of Muslim Consumers' Intention Toward...

own words and reactions, which is normally difficult to obtain using other methods (Ghauri \& Gronhaug, 2002).

Two focus group discussions involving 10 existing Muslim consumers' who are purchased goat's milk were conducted in February 2018 at the meeting room of the faculty. Respondents have been chosen based on their consistency in consuming and purchasing goat's milk. Participants were asked about their motives in the context of purchasing goat's milk. The questions were mostly open-ended. First questions were asked to participants is "did you purchase goat's milk?". Second, participants of focus group discussions were asked: “did you consume goat's milk?”. Main objective questions of this study are "what is the motives of you to purchase goat's milk?" were asked to participants.

To analyze the focus group discussion, the method suggested by Krueger and Casey (2000) has been followed. All of the focus groups discussions were audiotaped and transcribed. After the focus groups discussions have been carefully typed, the transcripts were reviewed so that the researchers could become familiar with the flow of the dialogue. All transcripts were merged and then all of the answers to question one from all the groups were moved to the same master document. This was done for each topic and question. From this master document (which contains all of the relevant responses), the patterns, trends or themes across all of the responses were examined.

\section{RESULT AND DISCUSSION}

For the purpose of reporting the results of the focus group discussions, findings are organized by topics that arose during focus group sessions that are relevant and pertinent to this study. Findings have been grouped according to the answers given on a specific question, yielding majority opinions and views. Table 1 below shows the demographic profiles of participants involved in the focus group discussions.

Table 1. Demographic Profiles

\begin{tabular}{lcll}
\hline \multicolumn{1}{c}{ Gender } & Age & \multicolumn{1}{c}{ Occupation } & \multicolumn{1}{c}{ Origin Place } \\
\hline Female & 35 & Banker & Kuala Lumpur \\
Female & 39 & Administrator & Selangor \\
Female & 45 & Lecturer & Negeri Sembilan \\
Female & 30 & Postgraduate student & Kelantan \\
Female & 27 & Postgraduate student & Selangor \\
Male & 29 & Researcher & Pulau Pinang \\
Female & 31 & Lecturer & Kuala Lumpur \\
Male & 30 & Administrator & Negeri Sembilan \\
Female & 34 & Lecturer & Terengganu \\
Male & 34 & Teacher & Pahang \\
\hline
\end{tabular}

In total, two focus group discussions were conducted consisting of 5 participants per group. The sample $(n=10)$ consisted of 7 female and 3 males with a mean age of 33.4 (range $=30-34$ years old). Each focus group discussion lasted between $45-60$ minutes. Participants come from various occupation background and most are working in private 
(e.g. banker and administrator) and government sector (e.g. researcher, lecturer, and the teacher). While the rest of the participants involved are postgraduate students in public university.

Participants were asked to reveal their motives of intention toward purchasing goat's milk. In general, the motives shared by the participants namely health, price, taste, nutrition, and religion. First, participants view health is the main factors of intent for them to purchase goat's milk. In modern society, health is one of the central values. The consumers are increasingly aware that food influences health condition (Yangilar, 2013). Findings from this study similar to findings from Leipamaa-Leskinen (2007) that health is an important motivating factor in food purchasing. The following are quotes that explain further motives of Muslim consumers' intention toward purchasing goat's milk due to health reason.

"Health factor is first pointed out in my mind when I purchase or consumed goat's milk because it contains many nutritious and benefit" (Female, aged 35).

"Goat's milk is highly nutritious and beneficial to human health. Thus, it becomes my intent and motivates me to purchase goat's milk products" (Female, aged 39).

"I have high blood pressure. Thus, to recover it I choose to purchase and consume goat's milk regularly. Because of it beneficial to my health" (Female, aged 45).

"Awareness of health care makes me consume and regularly purchase goat's milk. Because goat's milk is better than other types of milk. And as what I know about goat's milk fact, it is the best after mother's milk" (Female, aged 30).

Thus, this statement is definitely similar to Ulusoy (2015) which revealed about nutritious components in goat's milk is almost the same as the breast's milk. Based on the above statement from participants, they define health as the major reason that motivates them to purchase goat's milk due to its nutritious contents and beneficial health. This statement similar to Park and Haenlein (2007) findings. Other participants were identified to have other motives that contribute to purchasing goat's milk. Health is not the only factor people take into account when choosing their food. There is a set of motives significance for many people such as sensory appeal, price, ethical concern, weight control, convenience, natural content, familiarity, etc (Gagic et al., 2014). The following statements are quotes that show participants motives toward intention in purchasing goat's milk.

"Nutritious contents information stick at the bottle of goat's milk was motivated me toward intent to purchase goat's milk” (Female, aged 27).

Thus, this statement is similar to Miller, Soederberg, and Cassady (2015). Nutrition knowledge could support the use of nutrition information on food label use in at least three ways. First, prior knowledge could enable consumers to pay attention to important information on a food label and to ignore marketing features that do not reflect salient nutritional qualities, which in turn minimizes information overload. Second, prior nutrition knowledge can facilitate comprehension of, and memory for, food label 
nutrition information. Third, prior nutrition knowledge could support the application of the comprehended and remembered information to food choice. Meanwhile, others have stated that what motivates them toward intention in purchasing goat's milk.

"The price of goat's milk is considered affordable for me. Thus, it becomes my motives toward intention in purchasing goat's milk” (Male, aged 29).

"Goat's milk price for $250 \mathrm{ml}$ per bottle around RM 5.00 to RM 6.50 depends on the area of sale, it is affordable to purchase and with nutritious contents and beneficial to health it is reasonable" (Female, aged 31 ).

This statement is similar to Jerop et al. (2013), consumers were willing to pay higher prices for goat's milk. This implies that many consumers of goat's milk did not mind the price of the milk, possibly because of the additional health benefits of goat's milk. Besides that, other participants stated what motives become their intention of purchasing goat's milk. The following statements are quotes such below:

“As we know, a Muslim require to find good things in life either for consumers' or use. Thus, goat's milk falls under good things which is halal and thoyib. As following religious claims, I have no doubt intended to purchase goat's milk" (Male, aged 30).

"As a Muslim, I follow the sunnah of Prophet Muhammad (PBUH). Goat's milk is part of the prophetic food which is consumed regularly by the Prophet. Thus, in order to get baroqah in this life and hereafter I choose to follow this sunnah by consuming and purchasing it regularly" (Female, aged 34).

Goat's milk is one of the sunnah food, which likely and consumed regularly by the Prophet Muhammad (PBUH) (Umar et al., 2017):

Abu Bakr Siddiq reported: As we went along with Allah's Messenger (PBUH) from Mecca to Medina, we passed by a shepherd and Allah's Messenger (PBUH) was feeling thirsty. He (Abu Bakr Siddiq) said: I milked for him a small quantity of milk (from his goat) and brought it to him (the Holy Prophet), and he drank it and I was very happy.

(Imam Muslim, translation by Abdul Hamid Siddiqui, Volume: The Book of Drinks (Kitab Al-Ashriba), Number 498).

Moreover, several factors have been identified to affect the intention of Muslim consumers to purchase goat's milk. According to Jerop et al. (2013), the major reason for purchasing goat's milk is taste and its wide usage in the household (for the purpose of cooking). Besides that, literature found consumers are intended to purchase if the taste is not being significantly compromised (Hung, Verbeke \& de Kok, 2016; Shan, Regan, Monahan, Li, Murrin, Lalor, Wall \& McConnon, 2016; Tobin, O’Sullivan, Hamill \& Kerry, 2014). Similar to this finding, one of the participants said that his motive to purchase because of the taste. For instance,

" Goat's milk has a different taste compared to other milk. The texture is viscous and it produces some odor that stimulates me having goat's milk frequently. Thus, it makes me intended to purchase goat's milk twice a week" (Male, aged 34). 


\section{CONCLUSION}

This study explores the motives of Muslim consumers' intention of purchasing goat's milk among Malaysian. From two focus group discussions conducted, the motives of Malaysian to purchase goat's milk is obtained. Health, price, taste, nutrition, and religion are the main reason for the Malaysian to purchase goat's milk. This study identified predictors that could be practically used as segmentation criteria by marketing managers in marketing strategy development. Moreover, this study provides better understandings on the literature of Muslim consumer's behavior intention toward goat's milk purchasing. Findings of this study are limited to reasons for people purchasing goat's milk. Therefore, it is suggested that future research should investigate factors impeding goat's milk purchasing behavior. The findings will guide the study of the next phase of the data analysis. In order to understand Muslim consumers' purchase behavior.

\section{Acknowledgments}

This research was funded by the Ministry of Higher Education (MOHE) under the Niche Research Grant Scheme (NRGS) USIM/NRGS_P6/FEM/8406/52113. Faculty of Economics and Muamalat. Universiti Sains Islam Malaysia.

\section{BIBLIOGRAPHY}

Becker, T., Benner, E., \& Glitsch, K. (2000). Consumer Perception of Fresh Meat Quality in Germany, British Food Journal, 102(3), 246-266, DOI: https://doi. org/10.1108/00070700010324763.

Bergeaud-Blackler, F., \& Bonne, K. (2006). D'une Consommation Occasionnelle A` Un Re'Gime Halal: Quelles Conse'Quences Sur La Sante'. Migrations Sante', 129(1).

Bihaqi. S. M., \& Jalal, H. (2010). Goat Odour in Milk and Its Prevention, Research Journal of Agricultural Sciences, 1, 487-490.

Bonne, K., \& Verbeke, W. (2006). Muslim Consumer's Attitude Towards Meat Consumption in Belgium: Insights from A Means-end Chain Approach. Anthropology of Food, 5, 1-24.

Bonne, K., Vermeir, I., Bergeaud-Blackler, F., \& Verbeke, W. (2007). Determinants of Halal Meat Consumption in France. British Food Journal, 109(5), 367-386, DOI: https://doi. org/10.1108/0070700710746786.

Chang, L. L., Rahman, A. H., Rahman, Z. A., Aris, M. S. M., Siew, H. K., \& Rani, M. D. M. (2016). Effects of Nutritional Health Consciousness on Consumer's Goat Milk Consumption. Man in India, 96(11), 4523-4537.

Chaubey, D. S., \& Zafar, S. M. T. (2010). Consumer Buying Motives and Perceptions of Mobile Phone Services: A Study of Consumers of Uttrakhand. Pragyan, 8(1), 1-14.

Department of Veterinary Perak. (2015). Perbandingan Komposisi Susu Kambing Dengan LainLain Susu. Laporan Kajian Perbandingan Susu di Malaysia. (Accessed on February 3, 2018).

Essoo, N., \& Dibb, S. (2004). Religious Influences on Shopping Behaviour: An Exploratory Study. Journal of Marketing Management, 20 (7-8), 683-712, DOI: https://doi. org/10.1362/0267257041838728.

Fotopoulos, C., \& Krystallis, A. (2002). Purchasing Motives and Profile of the Greek Organic Consumer: A Countrywide Survey. British Food Journal, 104(9), 730-765, DOI: https:// doi.org/10.1108/00070700210443110.

Gagic, S., Jovičić, A., Tešanović, D., \& Kalenjuk, B. (2014). Motives for Food Choice Among 
Serbian Consumers. Economics of Agriculture, 1, UDC: 641.033:366.1(497.11).

Gerritsen, A. (2011). Focus Group Discussions - A Step-by-Step Guide. University of Limpopo and VLIR project South Africa.

Ghauri, P. N., \& Grønhaug, K. (2002). Research Methods in Business Studies: A Practical Guide. (2nd edition), London: FT Prentice Hall Europe.

Guney. I., \& Ocak, S. (2013). Consumers' Preference for Goat Milk in Turkey. Global Advanced Research Journal of Agricultural Science, 2(7), 181-188.

Haenlein, G. F. W. (2004). Goat Milk in Human Nutrition. Small Ruminant Research. 51(2), $155-$ 163, DOI: https://doi.org/10.1016/j.smallrumres.2003.08.010.

Haris, A., \& Kamarubahrin, A. F. (2016). A study of Malaysian Education and Purchasing Patterns on Prophetic Foods. In Yusoff, M. Y., Ahmad, K., \& Abd Razak, M. 4 (207-216). Research on Foods: Nabawi and Scientific Perspective. The International Conference on Food Research Based on Sunnah Nabawiah. University Malaya, Kuala Lumpur.

Haris, A., Kefeli, Z., Ahmad, N., Daud, S. N. M., Muhamed, N. A., Shukor, S. A., \& Kamarubahrin, A. F. (2017). Consumers' Intention to Purchase Dates: Application of Theory of Reasoned Action (TRA). Malaysian Journal of Consumer Family Economics, 20, 1 - 15.

Harden, C. J., \& Hepburn, N. J. (2011). The Benefits of Consuming Goat's Milk. Centre for Food Innovation, Sheffield Business School, Sheffield Hallam University, South Yorkshire, England. pp. 14.

Hung, Y., Verbeke, W., \& de Kok, T. M. (2016). Stakeholder and Consumers' Reactions Towards Innovative Processed Meat Products: Insights from A Qualitative Study About Nitrite Reduction and Phytochemical Addition. Food Control, 60, 690-698.

Imam Muslim, translation by Abdul Hamid Siddiqui, Volume: The Book of Drinks (Kitab Al-Ashriba), Number 498.

Jerop, R., Kosgey, I. S., Owuor, G. O., \& Chelanga, P. K. (2013). Consumers' Willingness to Pay for Dairy Goat Milk in Siaya County, Kenya. Livestock Research for Rural Development, 25, Article \#123. [Online] Available: http://www.lrrd.org/lrrd25/7/jero25123.htm.

Kamarubahrin, A. F. (2019). Muslim Consumer Intention toward Goat Milk Purchasing Behaviour in Malaysia: A Preliminary Findings. International Journal of Management, Accounting and Economics, 6(1), 62-79.

Kamarubahrin, A. F., Haris, A., Shukor, S. A., \& Shaari, J. A. N. (2018). A Review on Critical Success Factors in the Dairy Sector. Advanced Science Letters, 24, 338-341.

Krueger, R. A., \& Casey, M. A. (2000). Focus groups: A Practical Guide for Applied Researchers. (3rd ed.). Thousand Oaks, CA: Sage Publication.

Krueger, R. A. (2002). Designing and Conducting Focus Group Interviews. University of Minnesota. 1-18.

Kumar, A. A., \& Babu, S. (2014). Factors Influencing Consumer Buying Behaviour with Special Reference to Dairy Products in Pondicherry State. International Monthly Refereed Journal of Research in Management and Technology, 3(1), 65-73.

Kurajdova, K., \& Petrovicova, J. T. (2015). Literature Review on Factors Influencing Milk Purchase Behaviour. International Review of Management and Marketing, 5(1), 9-25.

Leipamaa-Leskinen, H. (2007). Contradictions in Food Consumption. International Journal of Consumer Studies, 31(6), 597-602, DOI: https://doi.org/10.1111/j.14706431.2007.00614.x.

Miller, L., Soederberg, M., \& Cassady, D. L. (2015). The Effects of Nutrition Knowledge on Food Label Use. A Review of the Literature. Appetite, 9(2), 207-216, DOI: 10.1016/j. appet.2015.05.029.

Mukhtar,A., \& Butt, M. M.(2012) Intention to Choose Halal products: The Role of Religiosity. Jour- 
nalofIslamic Marketing, 3(2), 108-120,DOI: https://doi.org/10.1108/17590831211232519

Park, Y. W., \& Haenlein G. F. W. (2007). Goat Milk, Its Products and Nutrition. In Hui YH (ed.): Handbook of Food Products Manufacturing. John Wiley New York, NY: pp. 447-486.

Rani, M. D. M., Umar, N. S., Ramli, S., Rahman, Z. A., Abdullah, M. Y., \& Salleh, N. M. (2016). Knowledge of Prophetic Food Consumption in Malaysia: Halal, Health Benefits and Practices. Contemporary Issues and Development in the Global Halal Industry, 45, 499-508.

Santoso, S. I., Setiadi, A., Kisworo, A. N., \& Nuswantara, L. K. (2012). Analysis Various Factors that Influence the Purchasing Behaviour of Goat Milk in Bogor Regency, Indonesia. International Journal of Engineering and Technology, 12(5), 124-131.

Shan, L. C., Regan, A., Monahan, F. J., Li, C., Murrin, C., Lalor, F., Wall, P. F., \& McConnon, A. (2016) Consumer Views on "Healthier" Processed Meat, British Food Journal, 118(7), 1712-1730, https://doi.org/10.1108/BFJ-11-2015-0447.

Siew, H. K., Rahman, H. A., Rahman, Z. A., Haris, A., Chang, L. L. \& Rani, M. D. M. (2016). A Mediating Effect of Food Neophobia toward Purchase Intention of Goat Milks among Malaysians Consumers. Man in India. 96(11), 4539-4552.

Solomon, M. R., Bamossy, G., Askegaard, S., \& Hogg, M. K. (2006). Consumers' Behaviour. A European Perspective. (3rd ed). Harlow, England, New York: Financial Times/Prentice Hall.

Tobin, B. D., O’Sullivan, M. G., Hamill, R., \& Kerry, J. P. (2014). European Consumers' Attitudes on The Associated Health Benefits of Nutraceutical-Containing Processed Meats Using Coenzyme Q10 as A Sample Functional Ingredient. Meat Science, 97(2), 207-213.

Turconi, G., Rossi, M., Roggi, C., \& Maccarini, L. (2013). Nutritional Status, Dietary Habits, Nutritional Knowledge and Self-Care Assessment in a Group of Older Adults Attending Community Centres in Pavia, Northern Italy. Journal Human Nutrition Dietary, 26, $48-55$.

Yangilar, F. (2013). As a Potentially Functional Food: Goats Milk and Products. Journal of Food and Nutrition Research, 1(4), 68-81. DOI:10.12691/jfnr-1-4-6.

Yusoff, S. H., \& Shukor, S. A. (2018). Exploring Motive of Purchasing Halal Cosmetic and Personal Care Product Among Muslim Women: A Focus Group Interview. In Supaat, D. I., Abdul Ghafar, A., \& Wook, I. 25(260-268). Contemporary Issues: Islam and Science. USIM Press.

Ulusoy, B. H. (2015). Nutritional and Health Aspects of Goat Milk Consumption. Akademik Glda, 13(1), 56-60.

Umar, N. S., Rani, M. D. M., Rahman, Z. A., Aripin, K. N. N., Adnan, F. H., Aris, M. S. M., \& Salleh, M. N. (2017). Goat's Milk Consumption Among Muslim Malaysian Residents in Pulau Langkawi, Kedah. Advanced Science Letters, 23(5). 4660-4663.

Utami, H. D. (2014). Consumers' Behaviour Toward Goat Milk and Its Processed Products in Malang, Indonesia. Journal of International Food and Agribusiness Marketing, 26(1), $1-12$. 